\title{
EVALUASI CAPAIAN TARGET RENCANA KERJA TERHADAP RENCANA STRATEGI BADAN PERENCANAAN PEMBANGUNAN DAERAH BAPPEDA PROVINSI KEPULAUAN BANGKA BELITUNG TAHUN 2017-2018
}

\author{
GUWITA SARI
}

Universitas Bangka Belitung

marita_heni@yahoo.co.id

\begin{abstract}
Abstrak
Penelitian ini bertujuan untuk melihat bagaimana evaluasi capaian target Rencana Kerja (Renja) terhadap Rencana Strategi (Renstra) Badan Perencanaan Pembangunan Daerah (BAPPEDA) di Provinsi Kepulauan Bangka Belitung Tahun 2017-2012. Dimana tujuan dari penelitian ini adalah untuk mengetahui dan menganalisis evaluasi capaian target Rencana Kerja (Renja) terhadap Rencana Strategi (Renstra) Badan Perencanaan Pembangunan Daerah (BAPPEDA) di Provinsi Kepulauan Bangka Belitung Tahun 2017-2012. Berdasarkan hasil penelitian dan pembahasan yang telah diuraikan sebelumnya mengenai evaluasi capaian target Rencana Kerja (Renja) terhadap Rencana Strategi (Renstra) BAPPEDA di Provinsi Kepulauan Bangka Belitung Tahun 2017-2012 bahwa program kegiatan dalam Rencana Kerja Perangkat Daerah (Renja PD) tahun 2018 sesuai dengan program kegiatan Rencana Strategi (Renstra PD).
\end{abstract}

Kata Kunci: Rencana Kerja, Rencana Straregi, BAPPEDA

\section{PENDAHULUAN}

Setiap Provinsi memerlukan suatu perencanaan daerah yang dijadikan pedoman atau acuan pelaksanaan program pembangunan daerah termasuk Organisasi Perangkat Daerah (OPD) yang merupakan perangkat daerah. Perencanaan pembangunan daerah merupakan suatu proses penyusunan tahapan-tahapan kegiatan yang melibatkan berbagai unsur pemangku kepentingan, guna pemanfaatan dan pengalokasian sumber daya yang ada, dalam rangka meningkatkan kesejahteraan sosial suatu lingkungan wilayah atau daerah untuk jangka waktu tertentu. Pelaksanaan perencanaan pembangunan daerah dirumuskan secara transparan, responsif, efisien, efektif, akuntabel, partisipatif, terukur, berkeadilan dan berwawasan lingkungan (Rencana Kerja, 2018).

BAPPEDA (Badan Perencanaan Pembangunan Daerah) adalah lembaga teknis dibidang penelitian dan perencanaan pembangunan daerah yang dipimpin oleh seorang kepala badan berada dibawah dan bertanggung jawab kepada Gubernur/Bupati/Walikota melalui Sektretaris Daerah. Badan tersebut mempunyai tugas pokok membantu Gubernur/Walikota/Bupati dalam penyelenggaraan Pemerintahan Daerah dibidang penelitian dan perencanaan pembangunan daerah (Rencana Pembangunan Jangka Menengah Daerah, 2017-2020). Perencanaan pembangunan melibatkan Rencana Kerja (Renja) yang merupakan penjabaran dari Rencana Kinerja Perangkat Daerah (RKPD) dalam waktu 1 (satu) tahun dan Rencana Strategi (Renstra) yang merupakan penjabaran Rencana Pembanguan Jangka Menengah Daerah (RPJMD) selama 5 (lima) tahun.

Evaluasi hasil Rencana Kerja Perangkat Daerah (Renja PD) dilakukan setiap triwulan sesuai dengan aliran dana dalam Dokumen Pelaksanaan Anggaran (DPA) tahun berjalan, berupa anggaran kas yang dibagi setiap triwulan. Perlu adanya Pengendalian dan evaluasi pelaksanaan rencana kerja yang dilakukan Badan Perencanaan Pembangunan dan Penelitian Pengembangan Daerah (BAPPEDA) untuk mengetahui data capaian kinerja dan evaluasi terkait pelaksanaan program kegiatan pada tahun berjalan. Evaluasi dilakukan terhadap program kegiatan yang telah dilaksanakan Badan Perencanaan Pembangunan Daerah Provinsi Kepulauan Bangka Belitung pada triwulan II Tahun 2018 sudah sesuai 
antara Rencana Kerja (Renja) terhadap Rencana Strategi (Renstra). Kondisi tersebut harus dicermati agar dapat diketahui realisasi dan capaian program-program Rencana Kerja (Renja) dan Rencana Strategi (Renstra) di Badan Perencanaan Pembangunan Daerah (BAPPEDA) Provinsi Kepulauan Bangka Belitung.

Program yang termuat dalam Rencana Kerja (Renja) selama 1 (satu) tahun harus berpedoman pada Rencana Strategi (Renstra) periode 5 (lima) tahun di Badan Perencanaan Pembangunan Daerah agar program tersebut berjalan semestinya. Capaian kinerja program tertinggi di Badan Perencanaan Pembangunan Daerah selama triwulan II tahun 2018 yaitu program peningkatan pelayanan pemerintah daerah dengan realisasi sebesar 32.40 persen dan capaian kinerja program terendah yaitu program perencanaan sosial, budaya dan pemerintahan sebesar 3.90 persen.

Berdasarkan latar belakang yang telah diuraikan, maka perumusan masalah dalam laporan ini adalah bagaimana evaluasi capaian target Rencana Kerja (Renja) terhadap Rencana Strategi (Renstra) Badan Perencanaan Pembangunan Daerah (BAPPEDA) di Provinsi Kepulauan Bangka Belitung Tahun 2017-2012. tujuan penelitian ini adalah untuk mengetahui dan menganalisis evaluasi capaian target Rencana Kerja (Renja) terhadap Rencana Strategi (Renstra) Badan Perencanaan Pembangunan Daerah (BAPPEDA) di Provinsi Kepulauan Bangka Belitung Tahun 2017-2012 .

\section{TINJAUAN PUSTAKA}

Secara garis besar dapat dikatakan bahwa evaluasi adalah pemberian nilai terhadap kualitas sesuatu. Selain dari itu, evaluasi juga dapat dipandang sebagai proses merencanakan, memperoleh, dan menyediakan informasi yang sangat diperlukan untuk membuat alternatif-alternatif keputusan (Purwanto, 2002).

Pendapat lain dikemukakan oleh Yusuf (2000) bahwa evaluasi adalah suatu usaha untuk mengukur dan sumber nilai secara objektif dari pencapaian hasil-hasil yang direncanakan sebelumnya, dimana hasil evaluasi tersebut dimaksudkan menjadi umpan balik untuk perencanaan yang akan dilakukan di depan (Yusuf,2000). Titik berat kajian evaluasi dari segi manajemen dan evaluasi merupakan salah satu fungsi atau unsur manajemen, dengan misi adalah untuk perbaikan fungsi atau sosial manajemen lainnya, yaitu perencanaan.

Evaluasi memiliki tiga fungsi utama dalam analisis kebijakan, yaitu:

a. Evaluasi memberi informasi yang salah dan dapat dipercaya mengenai kinerja kebijakan, yaitu seberapa jauh kebutuhan, nilai dan kesempatan yang telah dapat dicapai melalui tindakan publik. Dalam hal ini evaluasi mengungkapkan seberapa jauh tujuan-tujuan tertentu dan target tertentu telah dicapai.

b. Evaluasi memberi sumbangan pada klarifikasi dan kritik terhadap nilai-nilai yang mendasari pemilihan tujuan dan target. Nilai diperjelas dengan mendefenisikan dan mengoperasikan tujuan dan target.

c. Evaluasi memberi sumbangan pada aplikasi metode-metode analisis lainnya, termasuk perumusan masalah dan rekomendasi. Informasi tentang tidak memadai kinerja kebijakan yang dapat memberi sumbangan pada perumusan ulang masalah kebijakan (Wahab, 2002).

\section{Renja (Rencana Kerja)}

Menurut Husein Umar (2009) "Rencana kerja adalah suatu proses yang tidak pernah berakhir, apabila rencana telah ditetapkan, maka dokumen mengenai perencanaan yang terkait harus diimplementasikan. Karena perencanaan atau rencana kerja adalah pemilihan sekumpulan kegiatan dan pengambilan keputusan tentang apa yang harus dilakukan, kapan, bagaimana, dan oleh siapa."

Rencana Kerja Perangkat Daerah yang merupakan rencana pembangunan tahunan Perangkat Daerah dan selanjutnya disebut Rencana Kerja Perangkat Daerah adalah dokumen perencanaan 
Perangkat Daerah untuk periode1 (satu) tahun. Berdasarkan Undang-Undang Nomor 23 tahun 2014 tentang Pemerintahan Daerah pasal 273 ayat 3 menyebutkan bahwa rencana kerja Perangkat Daerah memuat program, kegiatan, lokasi, dan kelompok sasaran yang disertai indikator kinerja dan pendanaan sesuai dengan tugas dan fungsi setiap Perangkat Daerah. Rencana Kerja Satuan Kinerja Perangkat Daerah (Renja SKPD) merupakan penjabaran Rencana Strategi Satuan Kinerja Perangkat Daerah (Renja SKPD) yang mengacu pada Rencana Kinerja Perangkat Daerah (RKPD) yang memberikan gambaran tentang programdan kegiatan yang akan dikerjakan oleh Satuan Kinerja Perangkat Daerah (SKPD) dalam satu tahun anggaran. Rencana Kerja Satuan Kinerja Perangkat Daerah (SKPD) menjawab pertanyaan apa yang menjadi tujuan, sasaran peningkatan pelayanan, target capaian kinerja, serta bagaimana pengorganisasian program dan kegiatan pelayanan sesuai tupoksinya (Rencana Kerja, 2018).

Rencana Kerja Badan Perencanaan Pembangunan Daerah (Renja BAPPEDA) Provinsi Kepulauan Bangka Belitung Tahun 2018 disusun melalui 4 (empat) tahapan yaitu pertama persiapan penyusunan Rencana Kerja; kedua penyusunan rancangan Rencana Kerja (Renja); ketiga pelaksanaan forum perangkat daerah; dan keempat penetapan Rencana Kerja (Renja). Tahap persiapan dimulai dengan menyusun rancangan keputusan Gubernur Kepulauan Bangka Belitung tentang pembentukan tim penyusun Rencana Kerja Badan Perencanaan Pembangunan Daerah Daerah (Renja BAPPEDA), orientasi mengenai Rencana Kerja Badan Perencanaan Pembangunan Daerah, penyusunan agenda kerja tim penyusun Rencana Kerja Badan Perencanaan Pembangunan Daerah (RENJA BAPPEDA) dan penyiapan data dan informasi perencanaan pembangunan daerah (Rencana Kerja Badan Perencanaan Pembangunan Daerah, 2018).

Rencana Kerja Satuan Kinerja Perangkat Daerah (Renja SKPD) memiliki fungsi yang sangat fundamental dalam sistem perencanaan daerah,karena Rencana Kerja Satuan Kinerja Perangkat Daerah (Renja SKPD) merupakan produk perencanaan pada unit organisasi pemerintah terendah dan terkecil. Rencana Kerja Satuan Kinerja Perangkat Daerah (Renja SKPD) berhubungan langsung dengan pelayanan pada masyarakat yang merupakan tujuan utama penyelenggaraan pemerintahan daerah. Kualitas penyusunan Rencana Kerja Satuan Kinerja Perangkat Daerah (Renja SKPD) menentukan kualitas pelayanan publik (Rencana Kerja Badan Perencanaan Pembangunan Daerah, 2018).

\section{Renstra (Rencana Strategi)}

Renstra (Rencana Strategi) adalah sebuah alat manajemen yang digunakan untuk mengelola kondisi saat ini untuk melakukan proyeksi kondisi pada masa depan, sehingga rencana strategis adalah sebuah petunjuk yang dapat digunakan organisasi dari kondisi saat ini untuk mereka bekerja menuju 5 sampai 10 tahun ke depan (Kerzner, 2001). Rencana Strategis Perangkat Daerah adalah dokumen perencanaan teknis operasional Perangkat Daerah yang merupakan penjabaran Rencana Pembanguanan Jangka Menengah Daerah (RPJMD) secara sistematis untuk kurun waktu 5 (lima) tahun. Dokumen Rencana Strategi Perangkat Daerah (Renstra PD) memuat tentang tujuan, sasaran, strategi, kebijakan, indikasi program/kegiatan, target indikator kinerja dan pagu dana indikatif serta sumber-sumber pembiayaan selama kurun waktu 5 (lima) tahun, yang mengacu pada tugas pokok dan fungsi perangkat daerah (Rencana Strategis, 2018).

Undang-Undang Nomor 23 Tahun 2014 Pasal 272 Ayat (1), bahwa "Perangkat Daerah menyusun rencana strategis dengan berpedoman pada Rencana Pembangunan Jangka Menengah Daerah (RPJMD)”. Sedangkan dalam Peraturan Menteri Dalam Negeri Nomor 86 Tahun 2017 Pasal 13 Ayat (1) menyatakan bahwa Rencana Strategi Perangkat Daerah sebagaimana dimaksud dalam Pasal 11 ayat (3) huruf a memuat tujuan, sasaran, program, dan kegiatan pembangunan dalam rangka pelaksanaan urusan pemerintahan wajib dan/atau urusan pemerintahan pilihan sesuai dengan tugas dan fungsi setiap Perangkat Daerah, yang disusun berpedoman kepada Rencana Pembagunan Jangka Menengah Daerah (RPJMD) dan bersifat indikatif (Rencana Pembagunan Jangka Menengah Daerah, 2018). 


\section{METODE}

Waktu yang penelitian ini dilaksanakan pada tanggal 31 Juli-7 September tahun 2018. Tempat pelaksanaan penelitian ini adalah di Badan Perencanaan Pembangunan Daerah (BAPPEDA) Provinsi Kepulauan Bangka Belitung. Jenis penelitian yang digunakan dalam laporan adalah deskriptif kualitatif. Alasan penggunaan metode deskriptif kualitatif karena dengan menggunakan metode penelitian kualitatif informasi didapatkan secara mendetail dan lebih dalam sehingga permasalahan yang terjadi di lapangan dapat difokuskan dan penelitian kualitatif membantu penulis untuk memaparkan lebih banyak informasi karena metode yang digunakan berupa wawancara dan obeservasi langsung saat melakukan penelitian.

\subsection{Jenis Data}

Penelitian yang dilakukan menggunakan 2 (dua) jenis data yaitu:

a. Data Primer

Data primer merupakan data diperoleh langsung dari sumber asalnya, data primer diperoleh melalui:

1. Observasi yaitu pengamatan langsung terhadap objek kajian yang sedang berlangsung untuk memperoleh keterangan dan informasi sebagai data yang akurat tentang hal-hal yang diteliti serta untuk mengetahui relevansi antara jawaban informan dengan kenyataan yang

2. Interview atau wawancara mendalam (in dept interview) yaitu mengadakan wawancara dengan informan yang bertujuan untuk menggali informasi yang lebih mendalam tentang berbagai aspek yang berhubungan dengan permasalahan penelitian. Adapun narasumber yang menjadi pada penelitian ini adalah:

a. Sekretaris Badan Perencanaan Pembangunan Daerah (BAPPEDA) Provinsi Kepulauan Bangka Belitung.

b. Pegawai Badan Perencanaan Pembangunan Daerah (BAPPEDA) Provinsi Kepulauan Bangka Belitung.

b. Data sekunder

Data sekunder adalah data yang telah diolah sebelumnya yang diperoleh melalui:

1. Studi kepustakaan

Studi kepustakaan merupakan langkah yang penting sekali dalam metode ilmiah untuk mencari sumber data sekunder yang akan mendukung penelitian dan untuk mengetahui sampai ke mana ilmu yang berhubungan dengan penelitian telah berkembang, sampai ke mana terdapat kesimpulan dan degeneralisasi yang pernah dibuat. Cara yang dilakukan dengan mencari data-data pendukung (data sekunder) pada berbagai literatur baik berupa buku-buku, dokumen-dokumen Rencana Kerja dan Rencana Strategis Badan Perencanaan Pembangunan Daerah, makalah-makalah hasil penelitian serta bahan-bahan referensi lainnya yang berkaitan dengan penelitian.

2. Dokumentasi

Arsip-arsip, laporan tertulis atau daftar inventaris yang diperoleh terkait dengan penelitian yang dilakukan.

\section{HASIL DAN PEMBAHASAN}

\section{Kesesuaian Antara Program Rencana Kerja Perangkat Daerah (Renja PD) Tahun 2018 Terhadap Rencana Strategi (Renstra PD) Badan Perencanaan Pembangunan Daerah (BAPPEDA) Tahun 2017-2022}

Badan Perencanaan Pembangunan dan Penelitian Pengembangan Daerah (BAPPEDA) Provinsi Kepulauan Bangka Belitung melaksanakan fungsi penunjang urusan pemerintahan di bidang perencanaan dan bidang penelitian. Pembangunan bidang pada Rencana Kinerja Perangkat Daerah (RKPD) Tahun 2018 dan program prioritas Provinsi Kepulauan Bangka Belitung pada Rencana Kinerja 
Perangkat Daerah (RKPD) Tahun 2018. Rencana Kerja Badan Perencanaan Pembangunan dan Penelitian Pengembangan Daerah (Renja BAPPEDA) Provinsi Kepulauan Bangka Belitung tahun 2018 mencakup 6 program dan 26 kegiatan.

Kesesuaian antara program kegiatan yang ada di Rencana Kerja (Renja) Badan Perencanaan Pembangunan dan Penelitian Pengembangan Daerah (BAPPEDA) Tahun 2018 dengan Rencana Strategis Badan Perencanaan Pembangunan Daerah (Renstra BAPPEDA) tahun 2017-2022, gambaran tersebut seperti tabel berikut ini.

Tabel 4.1 Kesesuaian Antara Program Rencana Kerja Perangkat Daerah (Renja PD) Tahun 2018 Terhadap Rencana Strategi (Renstra PD) Badan Perencanaan Pembangunan Daerah (BAPPEDA) Tahun 2017-2022

\begin{tabular}{|c|c|c|c|}
\hline No & $\begin{array}{c}\text { Program Rencana Kerja } \\
\text { Perangkat Daerah (Renja PD) } \\
\text { Tahun } 2018\end{array}$ & $\begin{array}{c}\text { Program/kegiatan Rencana } \\
\text { Strategi (Renstra PD) } \\
\text { Tahun 2017-2022 }\end{array}$ & Keterangan \\
\hline $\mathbf{I}$ & $\begin{array}{l}\text { Program Peningkatan } \\
\text { Pelayanan Pemerintah }\end{array}$ & $\begin{array}{l}\text { Program Pelayanan } \\
\text { Administrasi Perkantoran }\end{array}$ & Sesuai \\
\hline 1 & $\begin{array}{l}\text { Pelayanan Administrasi } \\
\text { Perkantoran }\end{array}$ & $\begin{array}{l}\text { Pelayanan Administrasi } \\
\text { Perkantoran }\end{array}$ & Sesuai \\
\hline 2 & $\begin{array}{l}\text { Peningkatan Sarana dan } \\
\text { Prasarana Aparatur }\end{array}$ & $\begin{array}{l}\text { Peningkatan Sarana dan } \\
\text { Prasarana Aparatur }\end{array}$ & Sesuai \\
\hline 3 & Peningkatan Disiplin Aparatur & Peningkatan Disiplin Aparatur & Sesuai \\
\hline 4 & $\begin{array}{l}\text { Peningkatan Kapasitas Sumber } \\
\text { Daya Aparatur }\end{array}$ & $\begin{array}{l}\text { Peningkatan Kapasitas Sumber } \\
\text { Daya Aparatur }\end{array}$ & Sesuai \\
\hline 5 & $\begin{array}{l}\text { Penyusunan Dokumen } \\
\text { Perencanaan Pembangunan }\end{array}$ & $\begin{array}{l}\text { Penyusunan Dokumen } \\
\text { Perencanaan Pembangunan }\end{array}$ & Sesuai \\
\hline 6 & $\begin{array}{l}\text { Penyusunan Pelaporan Capaian } \\
\text { Kinerja dan Keuangan }\end{array}$ & $\begin{array}{l}\text { Penyusunan Pelaporan Capaian } \\
\text { Kinerja dan Keuangan }\end{array}$ & Sesuai \\
\hline 7 & $\begin{array}{l}\text { Rapat Koordinasi Nasional } \\
\text { Perencanaan Pembangunan }\end{array}$ & $\begin{array}{l}\text { Rapat Koordinasi Nasional } \\
\text { Perencanaan Pembangunan }\end{array}$ & Sesuai \\
\hline II & $\begin{array}{l}\text { Program Perencanaan, } \\
\text { Evaluasi dan Informasi } \\
\text { Pembangunan Daerah }\end{array}$ & $\begin{array}{l}\text { Program Perencanaan, } \\
\text { Evaluasi dan Informasi } \\
\text { Pembangunan Daerah }\end{array}$ & Sesuai \\
\hline 1 & $\begin{array}{l}\text { Penyusunan Dokumen } \\
\text { Perencanaan Pembangunan } \\
\text { Daerah }\end{array}$ & $\begin{array}{l}\text { Penyusunan Dokumen } \\
\text { Perencanaan Pembangunan } \\
\text { Daerah }\end{array}$ & Sesuai \\
\hline 2 & $\begin{array}{l}\text { Pengembangan Sistem Informasi } \\
\text { Perencanaan Pembangunan } \\
\text { Daerah }\end{array}$ & $\begin{array}{l}\text { Pengembangan Sistem } \\
\text { Informasi Perencanaan } \\
\text { Pembangunan Daerah }\end{array}$ & Sesuai \\
\hline
\end{tabular}




\begin{tabular}{|c|c|c|c|}
\hline No & $\begin{array}{c}\text { Program Rencana Kerja } \\
\text { Perangkat Daerah (Renja PD) } \\
\text { Tahun } 2018\end{array}$ & $\begin{array}{c}\text { Program/kegiatan Rencana } \\
\text { Strategi (Renstra PD) } \\
\text { Tahun 2017-2022 }\end{array}$ & Keterangan \\
\hline 3 & $\begin{array}{l}\text { Pengendalian, Evaluasi dan } \\
\text { Pelaporan Rencana } \\
\text { Pembangunan Daerah }\end{array}$ & $\begin{array}{l}\text { Pengendalian, Evaluasi dan } \\
\text { Pelaporan Rencana } \\
\text { Pembangunan Daerah }\end{array}$ & Sesuai \\
\hline 4 & $\begin{array}{l}\text { Pengembangan Sistem Informasi } \\
\text { Pengendalian dan Evaluasi } \\
\text { Rencana Pembangunan Daerah }\end{array}$ & $\begin{array}{l}\text { Pengembangan Sistem } \\
\text { Informasi Pengendalian dan } \\
\text { Evaluasi Rencana Pembangunan } \\
\text { Daerah }\end{array}$ & Sesuai \\
\hline 5 & $\begin{array}{l}\text { Pengembangan Data dan } \\
\text { Informasi Perencanaan } \\
\text { Pembangunan Daerah }\end{array}$ & $\begin{array}{l}\text { Pengembangan Data dan } \\
\text { Informasi Perencanaan } \\
\text { Pembangunan Daerah }\end{array}$ & Sesuai \\
\hline 6 & $\begin{array}{l}\text { Penyusunan Rumusan Kebijakan } \\
\text { Percepatan Pembangunan } \\
\text { Daerah }\end{array}$ & $\begin{array}{l}\text { Penyusunan Rumusan } \\
\text { Kebijakan Percepatan } \\
\text { Pembangunan Daerah }\end{array}$ & Sesuai \\
\hline III & $\begin{array}{l}\text { Program Perencanaan } \\
\text { Infrastruktur dan Kewilayahan }\end{array}$ & $\begin{array}{l}\text { Program Perencanaan } \\
\text { Infrastruktur dan Kewilayahan }\end{array}$ & Sesuai \\
\hline 1 & $\begin{array}{l}\text { Perencanaan Sub Bidang } \\
\text { Infrastruktur dan Pengembangan } \\
\text { Wilayah I }\end{array}$ & $\begin{array}{l}\text { Perencanaan Sub Bidang } \\
\text { Infrastruktur dan Pengembangan } \\
\text { Wilayah I }\end{array}$ & Sesuai \\
\hline 2 & $\begin{array}{l}\text { Perencanaan Sub Bidang } \\
\text { Infrastruktur dan Pengembangan } \\
\text { Wilayah II }\end{array}$ & $\begin{array}{l}\text { Perencanaan Sub Bidang } \\
\text { Infrastruktur dan Pengembangan } \\
\text { Wilayah II }\end{array}$ & Sesuai \\
\hline IV & $\begin{array}{l}\text { Program Perencanaan } \\
\text { Perekonomian dan Sumber } \\
\text { Daya Alam }\end{array}$ & $\begin{array}{l}\text { Program Perencanaan } \\
\text { Perekonomian dan Sumber } \\
\text { Daya Alam }\end{array}$ & Sesuai \\
\hline 1 & $\begin{array}{l}\text { Perencanaan Sub Bidang } \\
\text { Perekonomian dan Sumber Daya } \\
\text { Alam I }\end{array}$ & $\begin{array}{l}\text { Perencanaan Sub Bidang } \\
\text { Perekonomian dan Sumber } \\
\text { Daya Alam I }\end{array}$ & Sesuai \\
\hline 2 & $\begin{array}{l}\text { Perencanaan Sub Bidang } \\
\text { Perekonomian dan Sumber Daya } \\
\text { Alam II }\end{array}$ & $\begin{array}{l}\text { Perencanaan Sub Bidang } \\
\text { Perekonomian dan Sumber } \\
\text { Daya Alam II }\end{array}$ & Sesuai \\
\hline 3 & $\begin{array}{l}\text { Penyusunan Study Perencanaan } \\
\text { Bidang Ekonomi dan SDA }\end{array}$ & $\begin{array}{l}\text { Penyusunan Study Perencanaan } \\
\text { Bidang Ekonomi dan SDA }\end{array}$ & Sesuai \\
\hline V & $\begin{array}{l}\text { Program Perencanaan Sosial, } \\
\text { Budaya dan Pemerintahan }\end{array}$ & $\begin{array}{l}\text { Program Perencanaan Sosial, } \\
\text { Budaya dan Pemerintahan }\end{array}$ & Sesuai \\
\hline 1 & $\begin{array}{l}\text { Perencanaan Sub Bidang Sosial, } \\
\text { Budaya dan Pemerintahan I }\end{array}$ & $\begin{array}{l}\text { Perencanaan Sub Bidang Sosial, } \\
\text { Budaya dan Pemerintahan I }\end{array}$ & Sesuai \\
\hline
\end{tabular}




\begin{tabular}{|c|c|c|c|}
\hline No & $\begin{array}{c}\text { Program Rencana Kerja } \\
\text { Perangkat Daerah (Renja PD) } \\
\text { Tahun } 2018\end{array}$ & $\begin{array}{c}\text { Program/kegiatan Rencana } \\
\text { Strategi (Renstra PD) } \\
\text { Tahun 2017-2022 }\end{array}$ & Keterangan \\
\hline 2 & $\begin{array}{l}\text { Perencanaan Sub Bidang Sosial, } \\
\text { Budaya dan Pemerintahan I }\end{array}$ & $\begin{array}{l}\text { Perencanaan Sub Bidang Sosial, } \\
\text { Budaya dan Pemerintahan I }\end{array}$ & Sesuai \\
\hline 3 & $\begin{array}{l}\text { Penyusunan Study Perencanaan } \\
\text { Bidang Sosial, Budaya dan } \\
\text { Pemerintahan }\end{array}$ & $\begin{array}{l}\text { Penyusunan Study Perencanaan } \\
\text { Bidang Sosial, Budaya dan } \\
\text { Pemerintahan }\end{array}$ & Sesuai \\
\hline VI & $\begin{array}{l}\text { Program Penelitian dan } \\
\text { Pengembangan }\end{array}$ & $\begin{array}{l}\text { Program Penelitian dan } \\
\text { Pengembangan }\end{array}$ & Sesuai \\
\hline 1 & $\begin{array}{l}\text { Penelitian Prioritas } \\
\text { Pembangunan Daerah }\end{array}$ & $\begin{array}{l}\text { Penelitian Prioritas } \\
\text { Pembangunan Daerah }\end{array}$ & Sesuai \\
\hline 2 & Penguatan Jaringan Kelitbangan & Penguatan Jaringan Kelitbangan & Sesuai \\
\hline 3 & $\begin{array}{l}\text { Penguatan Sistem Inovasi } \\
\text { Daerah }\end{array}$ & $\begin{array}{l}\text { Penguatan Sistem Inovasi } \\
\text { Daerah }\end{array}$ & Sesuai \\
\hline 4 & Kajian Sciene Technology Park & Kajian Sciene Technology Park & Sesuai \\
\hline 5 & $\begin{array}{l}\text { Peningkatan Peran Dewan Riset } \\
\text { Daerah Dalam Pembangunan }\end{array}$ & $\begin{array}{l}\text { Peningkatan Peran Dewan Riset } \\
\text { Daerah Dalam Pembangunan }\end{array}$ & Sesuai \\
\hline
\end{tabular}

Sumber : Bappeda, diolah 2018

Berdasarkan Tabel 4.1 program Rencana Kerja (Renja) Badan Perencanaan Pembangunan Daerah (BAPPEDA) tahun 2018 berjumlah 6 program dan program-program kerja didukung oleh 26 kegiatan. Program-program yang termuat dalam Rencana kerja sudah sesuai dengan Rencana Strategis (Renstra) Badan Perencanaan Pembangunan Daerah (BAPPEDA) yang akan dilaksanakan dalam kurun waktu 5 tahun dijabarkan oleh Rencana Kerja (Renja). Program-program yang termuat dalam Rencana Kerja harus sesuai dengan Rencana Stategi supaya pembangungan daerah menjadi terarah dan berjalan dengan baik.

Program Rencana Kerja Badan Perencanaan Pembangunan Daerah (Renja BAPPEDA) Tahun 2018 sudah 100 (seratus) persen sesuai dengan program Rencana Strategi Perangkat Daerah (Renstra PD). Semua kegiatan yang telah dilaksanakan alam Renja Rencana Kerja (Renja) 1 tahun Badan Perencanaan Pembangunan Daerah (BAPPEDA) Provinsi Kepulauan Bangka Belitung Tahun 2018 sudah berpedoman pada Rencana Strategis pembangunan Daerah 5 tahun kedepan sehingga pembangunan OPD (Organisasi Perangkat Daerah) sesuai atau searah dengan pembangunan pemerintah daerah agar terlaksana dengan baik, efektif, efisien,transparan dan akuntabel.

\section{Evaluasi Realisasi Target Kinerja dan Penyerapan Anggaran Badan}

Evaluasi realisasi target kinerja dan penyerapan anggaran program Rencana Kerja Badan Perencanaan Pembangunan dan Penelitian Pengembangan Daerah (Renja BAPPEDA) Provinsi Kepulauan Bangka Belitung triwulan II Tahun 2018 dihitung berdasarkan laporan hasil realisasi pelaksanaan Renja yang terdapat pada dokumen perubahan pelaksanaan Anggaran Badan Perencanaan Pembangunan Daerah (APBD) Provinsi Kepulauan Bangka Belitung triwulan II Tahun 2018. 
Persentase target kinerja dan penyerapan anggaran dari Badan Perencanaan Pembangunan dan Penelitian Pengembangan Daerah (BAPPEDA) Provinsi Kepulauan Bangka Belitung dilakukan dengan menghitung rata-rata persentase capaian masing-masing kegiatan dari program yang dilaksanakan pada Badan Perencanaan Pembangunan (BAPPEDA) Provinsi Kepulauan Bangka Belitung diatur dalam Peraturan Menteri Dalam Negeri Nomor 86 Tahun 2017 tentang Tata Cara Perencanaan, Pengendalian dan Evaluasi Pembangunan Daerah, Tata Cara Evaluasi Rancangan Peraturan Daerah Tentang, Rencana Pembangunan Jangka Panjang Daerah dan Rencana Pembangunan Jangka Menengah Daerah, serta Tata Cara Perubahan Rencana Pembangunan Jangka Panjang Daerah dan Rencana Pembangunan Jangka Menengah Daerah, dan Rencana Kerja Pemerintah Daerah. Rata-rata capaian kinerja Badan Perencanaan Pembangunan Daerah diolah menjadi rata-rata capaian kinerja dan penyerapan anggaran Provinsi Kepulauan Bangka Belitung dengan menghitung rata-rata capaian kinerja dan penyerapan anggaran dari Perangkat Daerah lain. Tabel 4.1 menyajikan capaian kinerja dan penyerapan anggaran program Badan Perencanaan Pembangunan dan Penelitian Pengembangan Daerah (BAPPEDA) Provinsi Kepulauan Bangka Belitung triwulan II Tahun 2018. Gambaran tersebut seperti pada tabel berikut ini:

Tabel 4.2 Capaian Kinerja dan Penyerapan Anggaran Program, Badan Perencanaan Pembangunan Daerah (BAPPEDA), Provinsi Kepulauan Bangka Belitung Triwulan II Tahun 2018

\begin{tabular}{|c|c|c|c|c|c|c|c|c|c|c|c|}
\hline & \multirow{2}{*}{\multicolumn{3}{|c|}{$\begin{array}{c}\text { Target kinerja dan } \\
\text { anggaran berjalan tahun } \\
2018 \text { (tahun n-1) yang } \\
\text { dievaluasi }\end{array}$}} & \multicolumn{4}{|c|}{$\begin{array}{c}\text { Realisasi Kinerja Pada } \\
\text { Triwulan }\end{array}$} & \multirow{2}{*}{\multicolumn{2}{|c|}{$\begin{array}{c}\text { Realisasi } \\
\text { Capaian } \\
\text { Kinerja } \\
\text { dan } \\
\text { Anggaran } \\
\text { Renja } \\
\text { SKPD yang } \\
\text { dievaluasi } \\
\text { (2018) }\end{array}$}} & \multirow{2}{*}{\multicolumn{2}{|c|}{$\begin{array}{c}\text { Tingkat } \\
\text { Capaian } \\
\text { Kinerja } \\
\text { dan } \\
\text { Realisasi } \\
\text { Anggaran } \\
\text { Renja } \\
\text { Tahun } \\
2018(\%)\end{array}$}} \\
\hline & & & & & I & & II & & & & \\
\hline \multirow[t]{2}{*}{ (1) } & \multicolumn{3}{|c|}{ (2) } & \multicolumn{2}{|r|}{ (3) } & \multicolumn{2}{|r|}{ (4) } & \multicolumn{2}{|c|}{ (5) } & \multicolumn{2}{|c|}{ (6) } \\
\hline & $\mathrm{K}$ & Satuan & $\mathrm{Rp}$ & $\mathrm{K}$ & $\mathrm{Rp}$ & K & $\mathrm{Rp}$ & $\mathrm{K}$ & $\mathrm{Rp}$ & $\mathrm{K}$ & $\mathrm{Rp}$ \\
\hline \multicolumn{12}{|l|}{ Non Urusan } \\
\hline \multirow[t]{2}{*}{$\begin{array}{l}\text { Program } \\
\text { Peningkatan } \\
\text { Pelayanan } \\
\text { Pemerintah }\end{array}$} & $\begin{array}{l}7 \\
0 . \\
7 \\
5\end{array}$ & & $\begin{array}{c}5,416,042 \\
650\end{array}$ & 0 & $\begin{array}{c}567,661,66 \\
9\end{array}$ & & & - & $\begin{array}{r}1,755 \\
819,3 \\
63\end{array}$ & & $\begin{array}{c}32.4 \\
\%\end{array}$ \\
\hline & $\begin{array}{l}7 \\
1 . \\
2 \\
5\end{array}$ & & & & & & & & & & \\
\hline $\begin{array}{l}\text { Pelayanan } \\
\text { Administrasi } \\
\text { Perkantoran }\end{array}$ & $\begin{array}{l}1 \\
0 \\
0\end{array}$ & Orang & $\begin{array}{l}2,249,821 \\
000\end{array}$ & 100 & $\begin{array}{c}471,627,27 \\
9\end{array}$ & 100 & $\begin{array}{l}701,87 \\
8,396\end{array}$ & $\begin{array}{c}10 \\
0\end{array}$ & $\begin{array}{r}1,173, \\
505,6 \\
75\end{array}$ & $\begin{array}{l}50 \\
\%\end{array}$ & $\begin{array}{c}52.2 \\
\%\end{array}$ \\
\hline $\begin{array}{l}\text { Peningkatan Sarana } \\
\text { dan Prasarana }\end{array}$ & $\begin{array}{l}1 \\
3\end{array}$ & Paket & $2,034,121$, & 1 & $70,886,000$ & 2 & 261,65 & 3 & 332,5 & $\begin{array}{l}23 \\
\%\end{array}$ & $\begin{array}{c}16.3 \\
\%\end{array}$ \\
\hline
\end{tabular}




\begin{tabular}{|c|c|c|c|c|c|c|c|c|c|c|c|}
\hline & \multirow{2}{*}{\multicolumn{3}{|c|}{$\begin{array}{c}\text { Target kinerja dan } \\
\text { anggaran berjalan tahun } \\
2018 \text { (tahun n-1) yang } \\
\text { dievaluasi }\end{array}$}} & \multicolumn{4}{|c|}{$\begin{array}{c}\text { Realisasi Kinerja Pada } \\
\text { Triwulan }\end{array}$} & \multirow{2}{*}{\multicolumn{2}{|c|}{$\begin{array}{c}\text { Realisasi } \\
\text { Capaian } \\
\text { Kinerja } \\
\text { dan } \\
\text { Anggaran } \\
\text { Renja } \\
\text { SKPD yang } \\
\text { dievaluasi } \\
\text { (2018) }\end{array}$}} & \multirow{2}{*}{\multicolumn{2}{|c|}{$\begin{array}{c}\text { Tingkat } \\
\text { Capaian } \\
\text { Kinerja } \\
\text { dan } \\
\text { Realisasi } \\
\text { Anggaran } \\
\text { Renja } \\
\text { Tahun } \\
2018(\%)\end{array}$}} \\
\hline & & & & & I & & II & & & & \\
\hline \multirow[t]{2}{*}{ (1) } & \multicolumn{3}{|c|}{ (2) } & \multicolumn{2}{|r|}{ (3) } & \multicolumn{2}{|c|}{ (4) } & \multicolumn{2}{|c|}{ (5) } & \multicolumn{2}{|c|}{ (6) } \\
\hline & K & Satuan & $\mathrm{Rp}$ & $\mathrm{K}$ & $\mathrm{Rp}$ & $\mathrm{K}$ & $\mathrm{Rp}$ & $\mathrm{K}$ & $\mathrm{Rp}$ & $\mathrm{K}$ & $\mathrm{Rp}$ \\
\hline Aparatur & & & 650 & & & & 4,000 & & $\begin{array}{r}40,00 \\
0\end{array}$ & & \\
\hline $\begin{array}{l}\text { Peningkatan } \\
\text { Disiplin Aparatur }\end{array}$ & $\begin{array}{l}1 \\
0 \\
0\end{array}$ & Orang & $\begin{array}{c}115,480,00 \\
0\end{array}$ & 0 & 0 & 100 & $\begin{array}{c}113,48 \\
7,000\end{array}$ & $\begin{array}{c}10 \\
0\end{array}$ & $\begin{array}{r}113,4 \\
87,00 \\
0\end{array}$ & $\begin{array}{c}10 \\
0 \\
\%\end{array}$ & $\begin{array}{c}98.3 \\
\%\end{array}$ \\
\hline $\begin{array}{l}\text { Peningkatan } \\
\text { Kapasitas Sumber } \\
\text { Daya Aparatur }\end{array}$ & $\begin{array}{l}6 \\
0\end{array}$ & $\%$ & $\begin{array}{c}234,336,00 \\
0\end{array}$ & 20 & $13,822,390$ & 20 & $\begin{array}{c}87,588 \\
, 298\end{array}$ & 40 & $\begin{array}{r}101,4 \\
10,68 \\
8\end{array}$ & $\begin{array}{l}67 \\
\%\end{array}$ & $\begin{array}{c}43.3 \\
\%\end{array}$ \\
\hline $\begin{array}{l}\text { Penyusunan } \\
\text { Dokumen } \\
\text { Perencanaan } \\
\text { Pembangunan }\end{array}$ & 2 & Dokumen & $99,740,000$ & 0 & 0 & 1 & $\begin{array}{c}1,200 \\
000\end{array}$ & 1 & $\begin{array}{r}1,200 \\
000\end{array}$ & $\begin{array}{l}50 \\
\%\end{array}$ & $1.2 \%$ \\
\hline $\begin{array}{l}\text { Penyusunan } \\
\text { Pelaporan Capaian } \\
\text { Kinerja dan } \\
\text { Keuangan }\end{array}$ & 7 & Laporan & $79,250,000$ & 0 & 0 & 4 & $\begin{array}{c}14,950 \\
, 000\end{array}$ & 4 & $\begin{array}{l}14,95 \\
0,000\end{array}$ & $\begin{array}{l}57 \\
\%\end{array}$ & $\begin{array}{c}18.9 \\
\%\end{array}$ \\
\hline $\begin{array}{l}\text { Rapat Koordinasi } \\
\text { Nasional } \\
\text { Perencanaan } \\
\text { Pembangunan }\end{array}$ & 1 & Rakor & $\begin{array}{c}603,294,00 \\
0\end{array}$ & 0 & $11,326,000$ & 0 & $\begin{array}{c}7,400 \\
000\end{array}$ & - & $\begin{array}{l}18,72 \\
6,000\end{array}$ & $\begin{array}{l}0 \\
\%\end{array}$ & $3.1 \%$ \\
\hline & & & $\begin{array}{l}5,416,042 \\
650\end{array}$ & & Rat: & -Rat & Capaian & Kine & ja $(\%)$ & $\begin{array}{l}50 \\
\%\end{array}$ & $\begin{array}{c}16.7 \\
\%\end{array}$ \\
\hline Perencanaan & & & & & & & Pre & dikat & inerja & $\begin{array}{l}\mathrm{Sa} \\
\text { ng } \\
\text { at } \\
\mathrm{Re} \\
\text { nd } \\
\text { ah }\end{array}$ & $\begin{array}{l}\text { Sang } \\
\text { at } \\
\text { Rend } \\
\text { ah }\end{array}$ \\
\hline
\end{tabular}




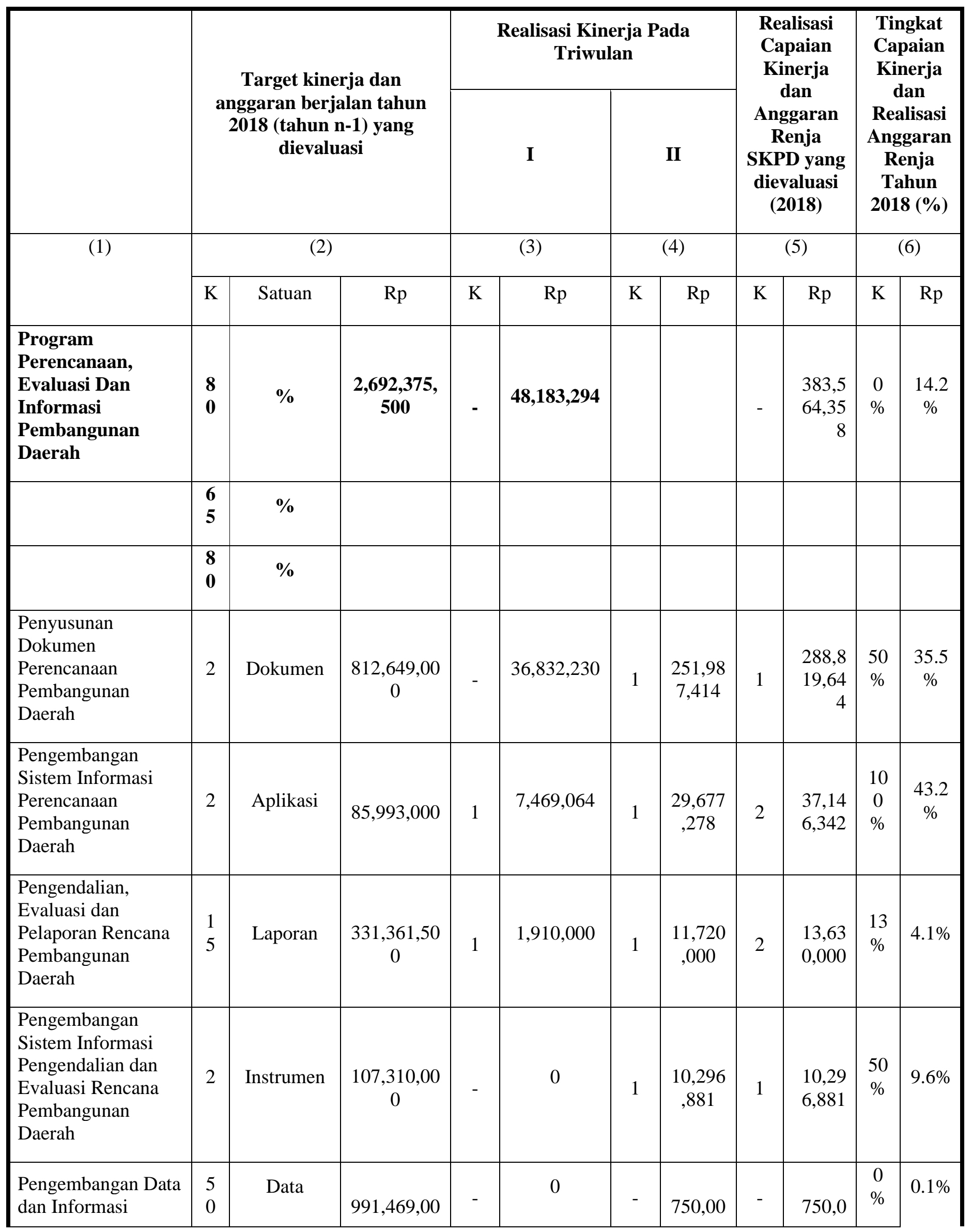




\begin{tabular}{|c|c|c|c|c|c|c|c|c|c|c|c|}
\hline & \multirow{2}{*}{\multicolumn{3}{|c|}{$\begin{array}{c}\text { Target kinerja dan } \\
\text { anggaran berjalan tahun } \\
2018 \text { (tahun n-1) yang } \\
\text { dievaluasi }\end{array}$}} & \multicolumn{4}{|c|}{$\begin{array}{c}\text { Realisasi Kinerja Pada } \\
\text { Triwulan }\end{array}$} & \multirow{2}{*}{\multicolumn{2}{|c|}{$\begin{array}{c}\text { Realisasi } \\
\text { Capaian } \\
\text { Kinerja } \\
\text { dan } \\
\text { Anggaran } \\
\text { Renja } \\
\text { SKPD yang } \\
\text { dievaluasi } \\
\text { (2018) }\end{array}$}} & \multirow{2}{*}{\multicolumn{2}{|c|}{$\begin{array}{c}\text { Tingkat } \\
\text { Capaian } \\
\text { Kinerja } \\
\text { dan } \\
\text { Realisasi } \\
\text { Anggaran } \\
\text { Renja } \\
\text { Tahun } \\
2018(\%)\end{array}$}} \\
\hline & & & & & $\mathbf{I}$ & & II & & & & \\
\hline \multirow[t]{2}{*}{ (1) } & \multicolumn{3}{|c|}{ (2) } & \multicolumn{2}{|r|}{ (3) } & \multicolumn{2}{|c|}{ (4) } & \multicolumn{2}{|c|}{ (5) } & \multicolumn{2}{|c|}{ (6) } \\
\hline & $\mathrm{K}$ & Satuan & $\mathrm{Rp}$ & $\mathrm{K}$ & $\mathrm{Rp}$ & $\mathrm{K}$ & $\mathrm{Rp}$ & $\mathrm{K}$ & $\mathrm{Rp}$ & K & $\mathrm{Rp}$ \\
\hline $\begin{array}{l}\text { Perencanaan } \\
\text { Pembangunan } \\
\text { Daerah }\end{array}$ & 0 & & 0 & & & & 0 & & 00 & & \\
\hline $\begin{array}{l}\text { Penyusunan } \\
\text { Rumusan Kebijakan } \\
\text { Percepatan } \\
\text { Pembangunan } \\
\text { Daerah }\end{array}$ & 6 & $\begin{array}{l}\text { laporan/rek } \\
\text { omendasi }\end{array}$ & $\begin{array}{c}363,593,00 \\
0\end{array}$ & 3 & $1,972,000$ & - & $\begin{array}{c}30,949 \\
, 491\end{array}$ & 1 & $\begin{array}{l}32,92 \\
1,491\end{array}$ & $\begin{array}{l}17 \\
\%\end{array}$ & $9.1 \%$ \\
\hline & & & $\begin{array}{l}2,692,375 \\
500\end{array}$ & \multicolumn{6}{|c|}{ Rata-Rata Capaian Kinerja (\%) } & $\begin{array}{l}38 \\
\%\end{array}$ & $\begin{array}{c}16.9 \\
\%\end{array}$ \\
\hline & & & & \multicolumn{6}{|c|}{ Predikat kinerja } & $\begin{array}{l}\text { Sa } \\
\text { ng } \\
\text { at } \\
\text { Re } \\
\text { nd } \\
\text { ah }\end{array}$ & $\begin{array}{l}\text { Sang } \\
\text { at } \\
\text { Rend } \\
\text { ah }\end{array}$ \\
\hline $\begin{array}{l}\text { Program } \\
\text { Perencanaan } \\
\text { Infrastruktur dan } \\
\text { Kewilayahan }\end{array}$ & $\begin{array}{l}8 \\
\mathbf{0}\end{array}$ & Persen & $\begin{array}{c}393,056,00 \\
0\end{array}$ & & $20,032,600$ & & & - & $\begin{array}{l}20,03 \\
2,600\end{array}$ & 0 & $5.1 \%$ \\
\hline $\begin{array}{l}\text { Perencanaan Sub } \\
\text { Bidang Infrstruktur } \\
\text { dan Pengembangan } \\
\text { Wilayah I }\end{array}$ & 4 & $\begin{array}{l}\text { Lap/rekom } \\
\text { endasi }\end{array}$ & $\begin{array}{c}259,342,00 \\
0\end{array}$ & - & $18,408,600$ & - & $\begin{array}{c}37,132 \\
, 478\end{array}$ & - & $\begin{array}{l}55,54 \\
1,078\end{array}$ & $\begin{array}{l}0 \\
\%\end{array}$ & $\begin{array}{c}21.4 \\
\%\end{array}$ \\
\hline \multirow[t]{2}{*}{$\begin{array}{l}\text { Perencanaan Sub } \\
\text { Bidang Infrstruktur } \\
\text { dan Pengembangan } \\
\text { Wilayah II }\end{array}$} & 4 & $\begin{array}{l}\text { Lap/rekom } \\
\text { endasi }\end{array}$ & $\begin{array}{c}133,714,00 \\
0\end{array}$ & - & $1,624,000$ & - & $\begin{array}{c}26,810 \\
, 993\end{array}$ & - & $\begin{array}{l}28,43 \\
4,993\end{array}$ & $\begin{array}{l}0 \\
\%\end{array}$ & $\begin{array}{c}21.3 \\
\%\end{array}$ \\
\hline & & & $393,056,00$ & \multicolumn{6}{|c|}{ Rata-Rata Capaian Kinerja (\%) } & $\begin{array}{l}0 \\
\%\end{array}$ & $\begin{array}{c}21.3 \\
\%\end{array}$ \\
\hline
\end{tabular}




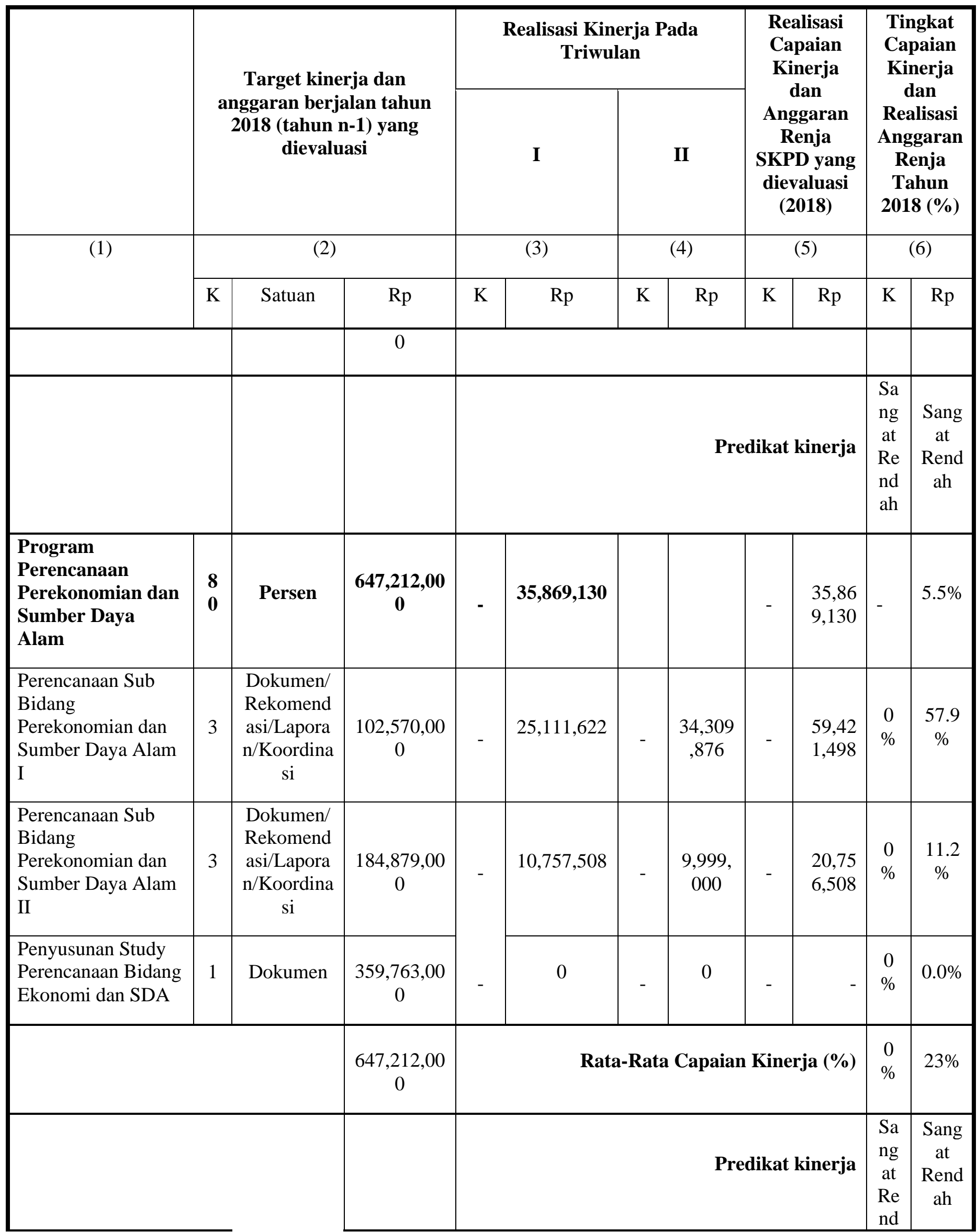




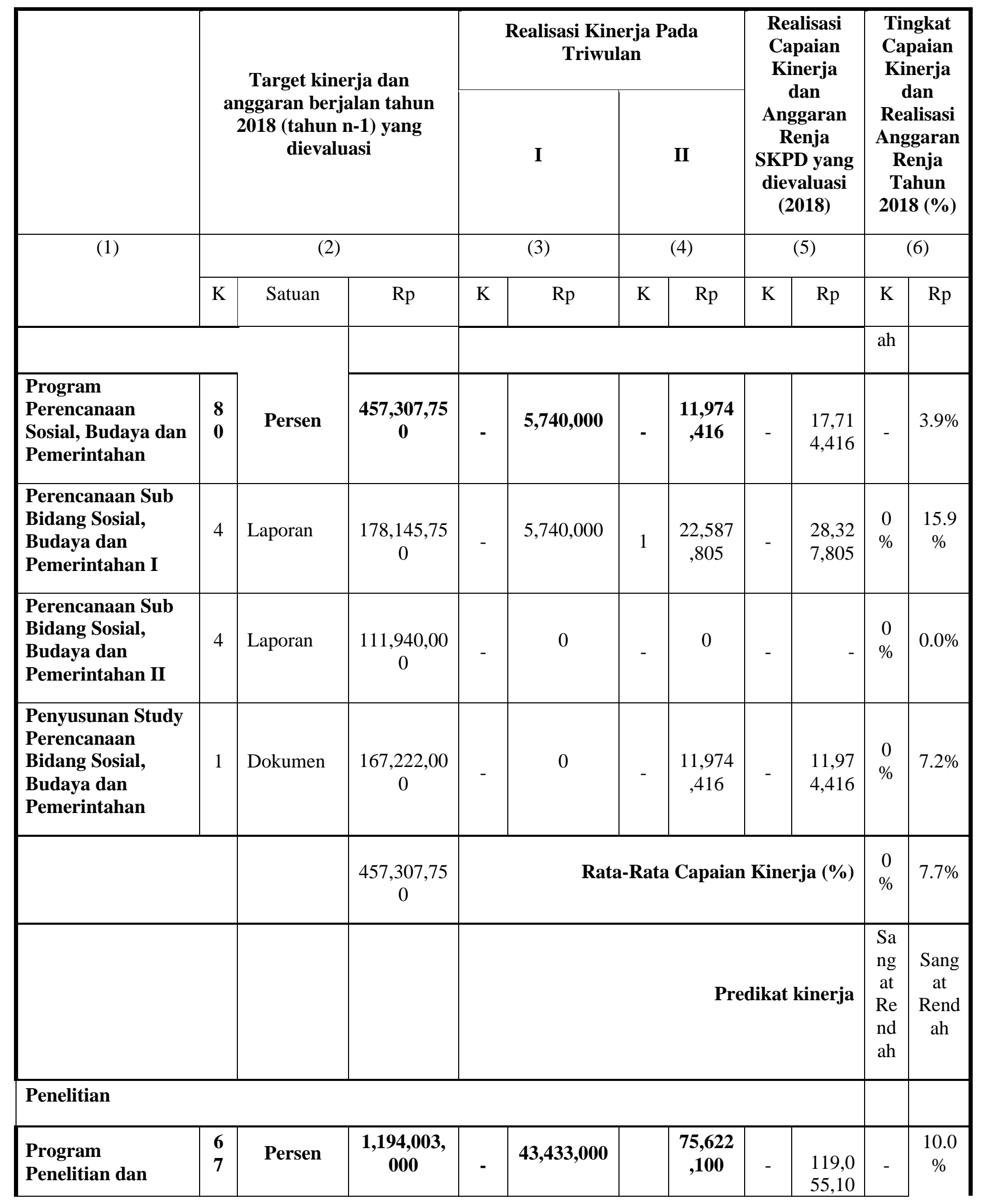




\begin{tabular}{|c|c|c|c|c|c|c|c|c|c|c|c|}
\hline & \multirow{2}{*}{\multicolumn{3}{|c|}{$\begin{array}{c}\text { Target kinerja dan } \\
\text { anggaran berjalan tahun } \\
2018 \text { (tahun n-1) yang } \\
\text { dievaluasi }\end{array}$}} & \multicolumn{4}{|c|}{$\begin{array}{c}\text { Realisasi Kinerja Pada } \\
\text { Triwulan }\end{array}$} & \multirow{2}{*}{\multicolumn{2}{|c|}{$\begin{array}{c}\text { Realisasi } \\
\text { Capaian } \\
\text { Kinerja } \\
\text { dan } \\
\text { Anggaran } \\
\text { Renja } \\
\text { SKPD yang } \\
\text { dievaluasi } \\
\text { (2018) }\end{array}$}} & \multirow{2}{*}{\multicolumn{2}{|c|}{$\begin{array}{c}\text { Tingkat } \\
\text { Capaian } \\
\text { Kinerja } \\
\text { dan } \\
\text { Realisasi } \\
\text { Anggaran } \\
\text { Renja } \\
\text { Tahun } \\
2018(\%)\end{array}$}} \\
\hline & & & & & I & & II & & & & \\
\hline \multirow[t]{2}{*}{ (1) } & \multicolumn{3}{|c|}{ (2) } & \multicolumn{2}{|r|}{ (3) } & \multicolumn{2}{|c|}{ (4) } & \multicolumn{2}{|c|}{ (5) } & \multicolumn{2}{|c|}{ (6) } \\
\hline & $\mathrm{K}$ & Satuan & $\mathrm{Rp}$ & $\mathrm{K}$ & $\mathrm{Rp}$ & $\mathrm{K}$ & $\mathrm{Rp}$ & K & $\mathrm{Rp}$ & K & $\mathrm{Rp}$ \\
\hline \multicolumn{12}{|l|}{ Pengembangan } \\
\hline $\begin{array}{l}\text { Penelitian Prioritas } \\
\text { Pembangunan } \\
\text { Daerah }\end{array}$ & 3 & Penelitian & $\begin{array}{c}266,498,00 \\
0\end{array}$ & - & 0 & - & $\begin{array}{c}27,690 \\
, 000\end{array}$ & - & $\begin{array}{l}27,69 \\
0,000\end{array}$ & $\begin{array}{l}0 \\
\%\end{array}$ & $\begin{array}{c}10.4 \\
\%\end{array}$ \\
\hline $\begin{array}{l}\text { Penguatan Jaringan } \\
\text { Kelitbangan }\end{array}$ & 3 & Kegiatan & $\begin{array}{c}201,164,00 \\
0\end{array}$ & - & $11,159,000$ & - & $\begin{array}{c}47,932 \\
, 100\end{array}$ & - & $\begin{array}{l}59,09 \\
1,100\end{array}$ & $\begin{array}{l}0 \\
\%\end{array}$ & $\begin{array}{c}29.4 \\
\%\end{array}$ \\
\hline $\begin{array}{l}\text { Penguatan Sistem } \\
\text { Inovasi Daerah }\end{array}$ & 1 & Dokumen & $\begin{array}{c}182,844,00 \\
0\end{array}$ & - & $8,438,000$ & & $\begin{array}{c}21,591 \\
, 900\end{array}$ & - & $\begin{array}{l}30,02 \\
9,900\end{array}$ & $\begin{array}{l}0 \\
\%\end{array}$ & $\begin{array}{c}16.4 \\
\%\end{array}$ \\
\hline $\begin{array}{l}\text { Kajian Science } \\
\text { Technology Park }\end{array}$ & 1 & Dokumen & $\begin{array}{c}223,932,00 \\
0\end{array}$ & - & $16,264,000$ & - & $\begin{array}{c}27,602 \\
, 000\end{array}$ & - & $\begin{array}{l}43,86 \\
6,000\end{array}$ & $\begin{array}{l}0 \\
\%\end{array}$ & $\begin{array}{c}19.6 \\
\%\end{array}$ \\
\hline \multirow[t]{3}{*}{$\begin{array}{l}\text { Peningkatan Peran } \\
\text { Dewan Riset Daerah } \\
\text { Dalam } \\
\text { Pembangunan }\end{array}$} & 6 & $\begin{array}{l}\text { Rekomend } \\
\text { asi }\end{array}$ & $\begin{array}{c}319,565,00 \\
0\end{array}$ & - & $7,572,000$ & - & $\begin{array}{c}23,586 \\
, 890\end{array}$ & - & $\begin{array}{l}31,15 \\
8,890\end{array}$ & $\begin{array}{l}0 \\
\%\end{array}$ & $9.8 \%$ \\
\hline & & & $\begin{array}{c}1,194,003 \\
000\end{array}$ & & & & & \multicolumn{2}{|c|}{$\begin{array}{l}\text { Rata-Rata } \\
\text { Capaian } \\
\text { Kinerja }(\%)\end{array}$} & $\begin{array}{c}0.0 \\
\%\end{array}$ & $\begin{array}{c}17.1 \\
\%\end{array}$ \\
\hline & & & & & $\begin{array}{l}720,919,69 \\
3\end{array}$ & & & \multicolumn{2}{|c|}{$\begin{array}{l}\text { Predikat } \\
\text { kinerja }\end{array}$} & $\begin{array}{l}\text { Sa } \\
\text { ng } \\
\text { at } \\
\text { Re } \\
\text { nd } \\
\text { ah }\end{array}$ & $\begin{array}{l}\text { Sang } \\
\text { at } \\
\text { Rend } \\
\text { ah }\end{array}$ \\
\hline \multirow{2}{*}{$\begin{array}{c}\text { JUMLAH } \\
\text { ANGGARAN } \\
\text { DAN REALISASI } \\
\text { DARI SELURUH } \\
\text { PROGRAM }\end{array}$} & & & \multirow[b]{2}{*}{$\begin{array}{c}\text { 10,799,996 } \\
, 900\end{array}$} & & & & & & & & \\
\hline & & & & \multicolumn{6}{|c|}{$\begin{array}{r}\text { TOTAL RATA-RATA CAPAIAN } \\
\text { KINERJA DAN ANGGARAN DARI } \\
\text { SELURUH PROGRAM }\end{array}$} & $\begin{array}{l}14 . \\
65 \\
\%\end{array}$ & $\begin{array}{l}17.1 \\
3 \%\end{array}$ \\
\hline
\end{tabular}




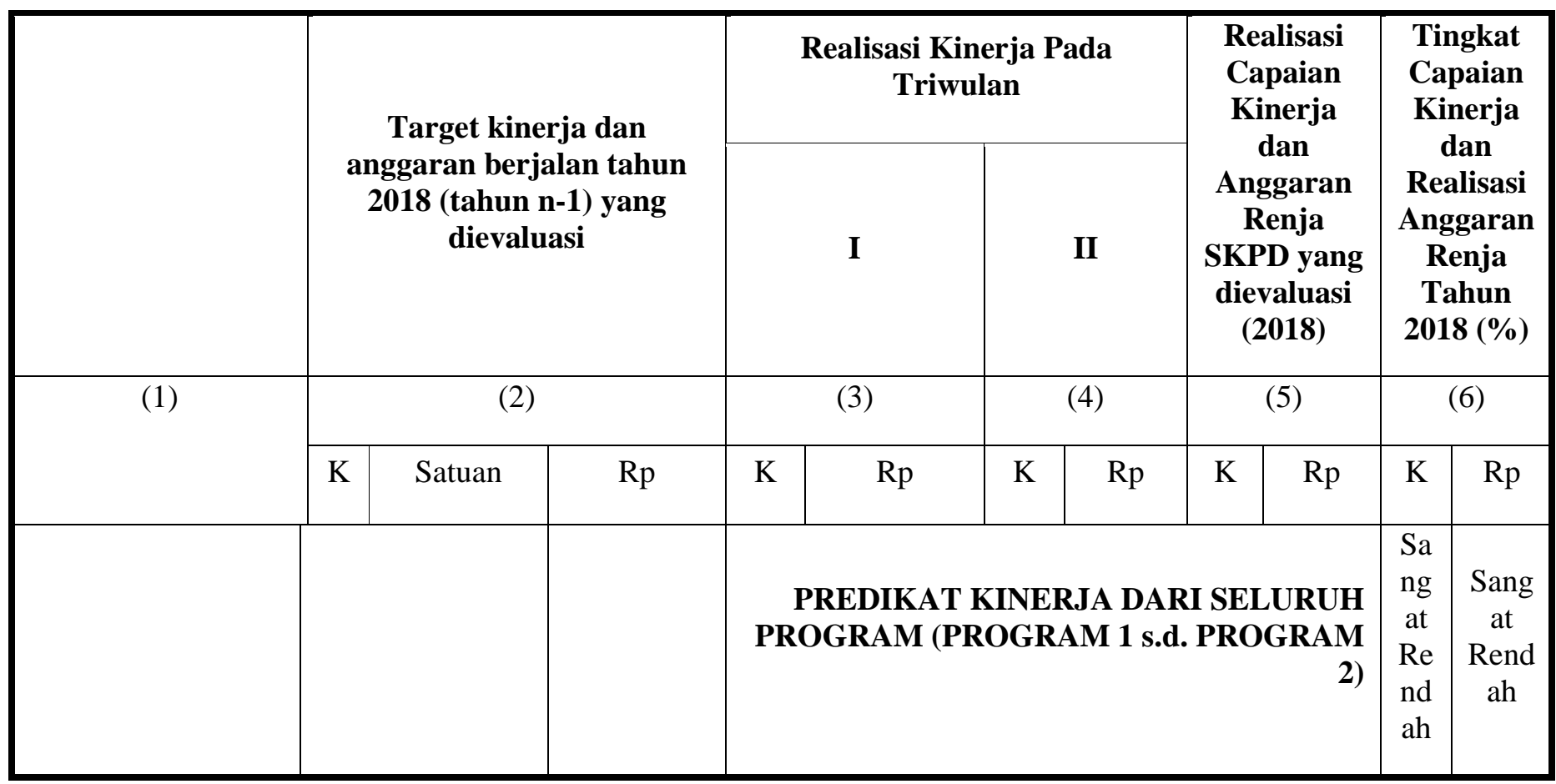

Sumber : Data evaluasi triwulan II Badan Perencanaan Pembangunan Daerah Provinsi Kepulauan

Bangka Belitung, 2018.

Keterangan:

$\begin{array}{lll}\text { SR } & : \text { Sangat Rendah } & (\leq 50 \text { persen }) \\ \mathrm{R} & : \text { Rendah } & (51 \text { persen } \leq 65 \text { persen }) \\ \text { S } & : \text { Sedang } & (66 \text { persen } \leq 75 \text { persen }) \\ \text { T } & : \text { Tinggi } & (76 \text { persen } \leq 90 \text { persen }) \\ \text { ST } & : \text { Sangat Tinggi } & (91 \text { persen } \leq 100 \text { persen })\end{array}$

Berdasarkan Tabel 4.2 terdapat 6 program yang dianggarkan oleh Anggaran Pendapatan Belanja Daerah (APBD) Tahun 2018. Untuk 26 kegiatan yang dilaksanakan, realisasi kinerja sampai dengan triwulan ke II sebesar 14,65 persen dengan predikat Sangat Rendah (SR) sedangkan untuk ratarata capaian keuangan seluruh program sebesar 17,13 persen dengan predikat Sangat Rendah (SR).

Selain itu untuk memastikan bahwa indikator kinerja program, kelompok sasaran, lokasi dan penyerapan dana indikatif kegiatan Rencana Kerja Badan Perencanaan Pembangunan dan Penelitian Pengembangan Daerah Provinsi Kepulauan Bangka Belitung dicapai, guna mewujudkan visi, misi Rencana Pembangunan Jangka Menengah Daerah (RPJMD) Provinsi Kepulauan Bangka Belitung serta prioritas dan sasaran pembangunan tahunan daerah Rencana Kerja Perangkat Daerah (RKPD) Tahun 2018 penjabarannya tertuang pada formulir Pengendalian dan Evaluasi terhadap Rencana Kerja Badan Perencanaan Pembangunan Daerah (Renja Bappeda) dan Penelitian Pengembangan Daerah Provinsi Kepulauan Bangka Belitung berdasarkan lampiran Peraturan Menteri Dalam Negeri (Permendagri) Nomor 86 tahun 2017. 
Tabel 4.3 Capaian Kinerja Program/ Kegiatan di Bappeda Provinsi Kepulauan Bangka Belitung TW II tahun 2018.

\begin{tabular}{|c|c|c|}
\hline No & Program/kegiatan & Capaian Kinerja Bappeda \\
\hline 1 & Program Peningkatan Pelayanan Pemerintah daerah & $32.40 \%$ \\
\hline 2 & $\begin{array}{l}\text { Program Perencanaan, Evaluasi Dan Informasi } \\
\text { Pembangunan Daerah }\end{array}$ & $14.20 \%$ \\
\hline 3 & $\begin{array}{l}\text { Program Perencanaan } \text { Infrastruktur dan } \\
\text { Kewilayahan }\end{array}$ & $5.10 \%$ \\
\hline 4 & $\begin{array}{l}\text { Program Perencanaan Perekonomian dan Sumber } \\
\text { Daya Alam }\end{array}$ & $5.50 \%$ \\
\hline 5 & $\begin{array}{l}\text { Program Perencanaan Sosial, Budaya dan } \\
\text { Pemerintahan }\end{array}$ & $3.90 \%$ \\
\hline 6 & Program Penelitian dan Pengembangan & $10.00 \%$ \\
\hline
\end{tabular}

Sumber : Bappeda, diolah 2018

Grafik 4.I Capaian Kinerja Badan Perencanaan Pembangunan Daerah

Provinsi Kepulauan Bangka Belitung Tahun 2018

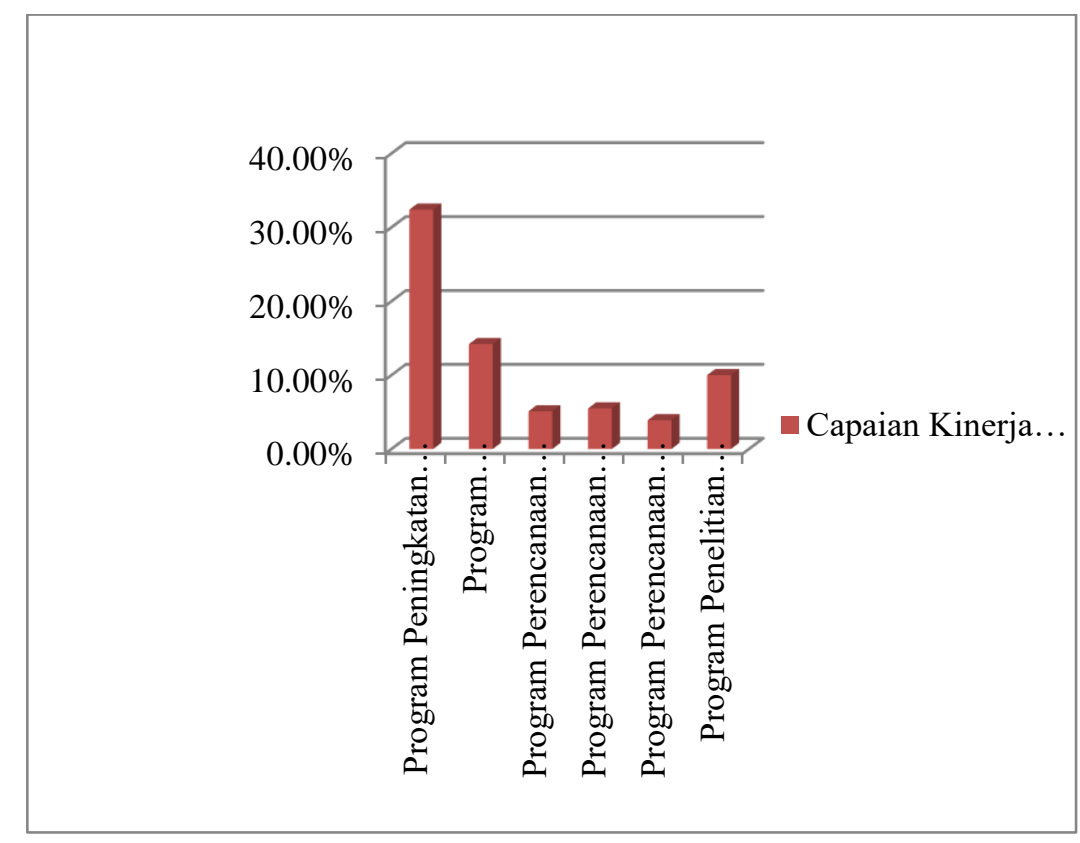

Sumber : data diolah, 2018

Berasarkan Grafik 4.1 Rencana Kerja Badan Perencanaan Pembangunan Daerah (Renja Bappeda) Provinsi Kepulauan Bangka Belitung Tahun 2018 berjumlah 6 Program. Program nilai capaian atau realisasi tertinggi adalah program peningkatan pelayanan pemerintah daerah dengan realisasi sebesar 32.40 persen yang didukung oleh kegiatan yaitu Pelayanan Administrasi Perkantoran, Peningkatan Sarana dan Prasarana Aparatur, Peningkatan Sumber Daya Kapasitas Aparatur, Penyusunan Dokumen Perencanaan Pembangunan, Penyusunan Pelaporan Capaian Kinerja dan Keuangan dan Rapat Koordinasi Nasinal Perencanaan Pembangunan. Program tersebut memiliki nilai capaian atau realisasi tertinggi tertinggi karena pengeluaran atau anggaran terhadap pengeluaran 
Program peningkatan pelayanan pemerintah daerah sebesar 32.4 persen sudah mendekati target capaian sebesar 70.75 persen. Pengeluaran terhadap anggaran Badan Perencanaan Pembangunan Daearah cenderung meningkat hingga triwulan II untuk mendukung kegiatan-kegiatan Badan Perencanaan Pembangunan Daerah seperti anggaran penyusunan Rencana Kerja Perangkat Daerah (RKPD), Rencana Pembangunan Jangka Menengah Daerah (RPJMD), Rapat Kerja Nasional (Rakornas) seIndonesia, serta peningkatan sarana dan prasarana Bappeda dan lain-lain. Selain itu program peningkatan pelayanan pemerintah merupakan program wajib yang harus dilaksanakan oleh setiap Organisasi Perangkat Daerah (OPD).

Program yang memiliki capaian atau realisasi terendah adalah program perencanaan sosial, budaya dan pemerintahan sebesar 3.90 persen. Program tersebut didukung oleh 3 kegiatan yaitu perencanaan sub bidang sosial, budaya, dan pemerintahan I, perencanaan sub bidang sosial, budaya, dan pemerintahan II, perencanaan sub bidang sosial, budaya, dan pemerintahan III. Program tersebut memiliki nilai capaian atau realisasi terendah karena pengeluaran atau anggaran terhadap pengeluaran program perencanaan sosial, budaya dan pemerintahan sebesar 3.9 persen belum mendekati target capaian sebesar 80 persen. Pengeluaran Badan Perencanaan Pembangunan Daearah terhadap kegiatan yang termuat dalam Rencana Kerja pada triwulan II belum sepenuhnya dilaksanakan dan kemungkinan dilaksanakan pada triwulan ke III dan IV. Selain itu program peningkatan pelayanan pemerintah merupakan bukan program utama yang harus dilaksanakan oleh setiap Organisasi Perangkat Daerah (OPD) pada awal triwulan sehingga penyerapan anggaran atau realisasi anggaran dapat dilaksanakan oleh Bappeda pada triwulan III dan IV dan kegiatan-kegiatan yang mendukung program tersebut dilaksanakan secara maksimal pada akhir triwulan.

\section{KESIMPULAN}

Berdasarkan hasil penelitian dan pembahasan yang telah diuraikan sebelumnya mengenai evaluasi capaian target Rencana Kerja (Renja) terhadap Rencana Strategi (Renstra) Badan Perencanaan Pembangunan Daerah (BAPPEDA) di Provinsi Kepulauan Bangka Belitung Tahun 20172012 bahwa program kegiatan dalam Rencana Kerja Perangkat Daerah (Renja PD) tahun 2018 sesuai dengan program kegiatan Rencana Strategi (Renstra PD), artinya semua kegiatan yang telah dilakasanakan Bappeda Provinsi Kepulauan Bangka Belitung dalam tahun 2018 yang dimuat dalam Renja (Rencana Kerja dalam 1 (satu) tahun sudah berpedoman atau mengacu pada Rencana Strategis pembangunan Daerah dalam 5 tahun kedepan.

Program-program yang dilaksanakan Badan Perencanaan Pembangunan Daerah Provinsi Kepulauan Bangka Belitung yang memiliki nilai capaian atau realisasi tertinggi adalah program Program Peningkatan Pelayanan Pemerintah daerah dengan realisasi sebesar 32.4 persen sedangkan program yang memiliki capaian atau realisasi terendah adalah program Program Perencanaan Sosial, Budaya dan Pemerintahan 3.90 persen.

\section{UCAPAN TERIMA KASIH}

Puji syukur penulis ucapkan atas kehadirat Allah SWT yang telah memberikan rahmat, hidayah, serta karunianya sehingga dapat menyelesaikan laporan kuliah kerja praktek yang berjudul "Evaluasi Capaian Target Rencana Kerja (Renja) Terhadap Rencana Strategi (Renstra) Badan Perencanaan Pembangunan Daerah (Bappeda) di Provinsi Kepulauan Bangka Belitung Tahun 2017-2012”.

Dalam penulisan laporan kuliah lapangan ini penulis mengucapkan terima kasih kepada:

1. Dr. Devi Valeriani, S.E., M.Si selaku Ketua Program Studi Ekonomi Fakultas Ekonomi Universitas Bangka Belitung.

2. M. Fikri Ashar, S. E., M. Si sebagai dosen pembimbing yang telah membimbing dan memberikan masukan kepada penulis untuk menyelesaikan kuliah lapangan ini. 
3. Bapak Fery Insani, SE., MM selaku Ketua Badan Perencanaan Pembangunan Daerah Provinsi Kepulauan Bangka Belitung (BAPPEDA) yang telah memberikan kesempatan buat kami untuk dapat melaksanakan kuliah lapangan di Badan Perencanaan Pembangunan Daerah Provinsi Kepulauan Bangka Belitung (BAPPEDA).

4. Ibu Vesriana, SE., MAP selaku Kepala Sub Bidang Perencanaan sebagai pembimbing lapangan yang telah memberikan masukan dan membimbing penulis dalam melaksanakan seluruh kegiatan kuliah lapangan dengan baik.

5. Penulis berterimakasih kepada orang tua serta teman-teman serta semua pihak yang tidak bisa disebutkan satu-persatu yang telah banyak membantu penulis dan dukungan yang tiada hentinya. Semoga Laporan Kuliah Kerja Praktek ini dapat bermanfaat bagi semua pihak terutama penulis dan pembaca.

\section{REFERENSI}

\section{Buku}

Abdul Wahab, Solichin. 2002. Analisis Kebijaksanaan, Dari Formulasi

KeImplementasi Kebijaksanaan Negara. Jakarta: Bumi Aksara

Bryson, M John. 2007. Perencanaan Strategis Bagi Organisasi Sosial. Yogyakarta : Pustaka Pelajar.

Husein Umar. 2009. Rencana Kerja Perusahaan Yang Baik. Jakarta: Rajawali.

Moleong.J.Lexy.2008. Metodologi penelitian kualitatif. Bandung: PT remaja Rosdakarya

Purwanto. 2002. Evaluasi Hasil Belajar, Yogyakarta: Pustaka Pelajar.

Yusuf, Farida. 2000. Evaluasi Program. Jakarta: Rineka Cipta.

For an organizational or government report or document with no author(s):

Badan Perencanaan Pembangunan Daerah. 2018. Data Evaluasi (Dalev) Rencana Kerja (Renja)Badan Perencanaan Pembangunan Daerah Provinsi Kepuluan Bangka Belitung Tahun 2018. Bangka Belitung.

Badan Perencanaan Pembangunan Daerah. 2018. Rencana Kerja (Renja) satuan kerja perangkat daerah (SKPD) Badan Perencanaan Pembangunan Daerah Provinsi Kepulauan Bangka Belitung Tahun 2018. Bangka Belitung.

Badan Perencanaan Pembangunan Daerah. 2017. Rencana Pembangunan Jangka Menengah Daerah (RPJMD) satuan kerja perangkat daerah (SKPD) Bappeda Provinsi Kepulauan Bangka Belitung Tahun 2017-2022. Bangka Belitung.

Badan Perencanaan Pembangunan Daerah. 2017. Rencana Strategi (Renstra) satuan kerja perangkat daerah (SKPD) Badan Perencanaan Pembangunan Daerah Provinsi Kepulauan Bangka Belitung Tahun 2018. Bangka Belitung 